\title{
Determination of Benzene and Toluene In Exhaled Cigarette Smoke*
}

\author{
by \\ Serban Moldoveanu, William Coleman III, and Jonathan Wilkins \\ R.J. Reynolds Tobacco Co., 950 Reynolds Boulevard, Winston-Salem, NC 27105, USA
}

\section{SUMMARY}

This study describes the results regarding the evaluation of retention efficiency by humans of benzene and toluene from cigarette smoke. The evaluated cigarette was a common commercial cigarette with $10.6 \mathrm{mg}$ 'tar' [U.S. Federal Trade Commission (FTC) 'tar' is defined as the weight of total particulate matter minus nicotine and water]. The test was performed on ten subjects. The exhaled smoke was collected using a vacuum assisted technique that avoids strain in exhaling the smoke. The study showed that benzene was retained at levels of $89 \%$ to $98 \%$, and toluene was retained at similar levels, between $87 \%$ and $99 \%$. The lower limits of retention for both benzene and toluene are unexpectedly low compared to the retention of bi-and tricyclic aromatic hydrocarbons, which have retentions from cigarette smoke above $95 \%$. This is probably caused by the fact that monocyclic aromatic hydrocarbons are present practically only in the vapor phase of cigarette smoke and at considerably higher levels than bi- and tri-cyclic aromatic hydrocarbons which are present almost completely in the particulate phase of cigarette smoke. [Beitr. Tabakforsch. Int. 23 (2008) 107-114]

\section{ZUSAMMENFASSUNG}

In dieser Arbeit werden die Ergebnisse einer Untersuchung über die Retentionseffizienz von Benzol und Toluol aus Zigarettenrauch beim Rauchen präsentiert. Bei der untersuchten Zigarette handelte es sich um eine handelsübliche Zigarette mit 10,6 mg Kondensat [Kondensat ist gemäß den Abrauchbedingungen der U.S. Federal Trade Commission (FTC) das Gewicht der nikotinfrein, Gesamtpartikelmasse unter Abzug von Wasser]. Die Untersuchung wurde mit 10 Testpersonen durchgeführt. Der exhalierte Rauch wurde in einem Vakuum-unterstützen Verfahren gesammelt, um einen Widerstand beim Exhalieren zu vermeiden. Die Untersuchung zeigte, dass Benzol zu 89 bis $98 \%$ retiniert wurde und Toluol in vergleichbarer Menge zwischen 87 und 99\%. Die unteren Grenzwerte für die Retention von Benzol und Toluol sind im Vergleich zur Retention von bi- und trizyklischen aromatischen Kohlenwasserstoffen, welche Retentionswerte aus dem Zigarettenrauch von über $95 \%$ besitzen, unerwartet niedrig. Dies liegt höchstwahrscheinlich daran, dass monozyklische aromatische Kohlenwasserstoffe lediglich in der Gasphase des Zigarettenrauchs vorkommen und in wesentlich höheren Konzentrationen enthalten sind als bi- und trizyklische aromatische Kohlenwasserstoffe, welche fast ausschließlich in der Partikelphase des Zigarettenrauchs vorkommen. [Beitr. Tabakforsch. Int. 23 (2008) 107-114]

\section{RESUME}

Les résultats d'une étude sur l'évaluation de l'efficacité de la rétention du benzène et du toluène dans la fumée de cigarette chez le fumeur sont présentés. La cigarette évaluée est une cigarette commerciale de $10,6 \mathrm{mg}$ de goudron [selon l'US Federal Trade Commission (FTC), le goudron est défini comme le poids de la matière particulaire totale exempte de nicotine et d'eau]. Dans cette étude, dix fumeurs ont fumé les cigarettes évaluées. La fumée exhalée a été échantillonnée à l'aide d'une technique sous vide pour éviter une trop grande résistance durant l'exhalation de la fumée. L'étude montre que le benzène est retenu de $89 \%$ à $98 \%$ et le toluène est retenu à un niveau comparable, entre $87 \%$ et $99 \%$. Les limites de rétention pour le benzène et le toluène sont plus faibles que celles attendues, comparées avec la rétention des hydrocarbures aromatiques bicycliques et tricycliques ayant des taux de rétention supérieurs à 95\%. Ceci est probablement due au fait que les hydrocarbures 
Table 1. Review of some previous studies on human retention from cigarette smoke of compounds other than nicotine

\begin{tabular}{|c|c|c|}
\hline Author(s) & Reference & Analytes \\
\hline Lehman (1909) & 1 & Ammonia, pyridine \\
\hline Laskowski (1951) & 16 & $\begin{array}{l}\text { Pyridine, ammonia, a few classes of compounds (free bases, aldehydes }+ \\
\text { ketones, free carbolic acids, etc.) }\end{array}$ \\
\hline Haagen-Smith et al. (1959) & 17 & $\mathrm{NO}_{\mathrm{x}}$ \\
\hline Dahlman et al. (1968) (two studies) & 13,14 & Acetaldehyde, acetone, acetonitrile, isoprene, toluene, $\mathrm{CO}$ \\
\hline Egle (1970) & 18 & Acetaldehyde \\
\hline Backhurst and Martin (1973) & as reported in 15 & Vapor phase constituents including benzene and toluene \\
\hline Ingebrethsen (1989) & 19 & Phenol, triacetin, neophytadiene, glycerin \\
\hline Armitage et al. (2004) (two studies) & 4,6 & Solanesol (and nicotine) \\
\hline Baker, Dixon (2006) & 15 & Review, also including some BAT internal reports \\
\hline Feng et al. (2006) & 20 & TSNAs, acetaldehyde, isoprene, ethylene \\
\hline
\end{tabular}

aromatiques monocycliques sont seulement présents dans la phase gazeuse de la fumée de cigarette et ceci pour des teneurs considérablement plus élevées que les hydrocarbures aromatiques bicycliques et tricycliques nettement plus présents dans la phase particulaire de la fumée de cigarette. [Beitr. Tabakforsch. Int. 23 (2008) 107-114]

\section{INTRODUCTION}

The analysis of chemical composition of exhaled cigarette smoke and its comparison with the composition of the inhaled smoke received attention for almost 100 years (1). However, most studies on smoke retention were focused on nicotine and total particular matter (TPM) (1-15). A summary of some older studies on the retention of other mainstream cigarette smoke components is given in Table 1. More recently, several new studies were performed on chemical composition of exhaled cigarette smoke (20-24). One of these studies (21) evaluated the overall comparison between delivered and exhaled smoke for the levels of 160 compounds that can be directly analyzed in a gas chromatographic (GC) profile. Other studies evaluated the retention by humans of specific groups of smoke constituents such as tobacco specific nitrosamines, isoprene, and ethylene (20), carbonyl compounds $(20,22)$, polycyclic aromatic hydrocarbons (23), and phenols (24). This present study describes the findings regarding the retention by humans from cigarette smoke of benzene and toluene.

\section{EXPERIMENTAL}

The experiments for the evaluation of benzene and toluene retention by human smokers were performed using a common commercial cigarette with $10.6 \mathrm{mg}$ 'tar' ('tar' is the weight of total particulate matter minus the weight of water and nicotine) as measured following U.S. Federal Trade Commission (FTC) recommendations. Other descriptors of the cigarette are cigarette length $83 \mathrm{~mm}$, filter length $27 \mathrm{~mm}$, filter ventilation $32 \%$, blend type American, nicotine $0.92 \mathrm{mg} / \mathrm{cig}$ and CO $10.7 \mathrm{mg} / \mathrm{cig}$. The number of smokers used in the present study was ten. For the measurement of the retention it was necessary to know both the level of benzene and toluene in the exhaled smoke as well as that from the delivered smoke. The benzene and toluene in the exhaled smoke were directly measured. The levels in the delivered smoke were obtained using dependence charts between the levels in smoke as a function of the nicotine level in the cigarette butt. These dependence charts were obtained by analyzing smoke generated with a smoking machine working under different regimes and simultaneously measuring the nicotine level in the cigarette butts. The whole procedure required several steps which included a) collection of samples from a smoking machine using a variety of smoking conditions, b) collection of exhaled smoke, c) measurement of benzene and toluene obtained from the smoking machine, or from the exhaled smoke, d) analysis of nicotine in the cigarette butts from the smoking machine, and from human smokers, and e) calculation of the results. Each of these steps is further discussed in detail.

\section{Collection of samples from smoking machine}

The particulate phase of cigarette smoke from five cigarettes was collected on one $92 \mathrm{~mm}$ Cambridge pad. The pad holder was connected to a charcoal trap for the collection of components from the vapor phase of cigarette smoke, and further to the pump of the smoking machine. The trap was an ORBO ${ }^{\text {TM}}$-32 Small trap (Supelco, Bellefonte, PA 16823-0048 USA) that contains the charcoal in two sections indicated as $\mathrm{A}$ and B. Section A of the tube contains $100 \mathrm{mg}$ absorbent charcoal and is designed to retain the analytes. Section B of the tube contains an additional $50 \mathrm{mg}$ absorbent charcoal and is used as backup in case of breakthrough of the analyte. Smoking was done initially in conditions similar to those recommended by the FTC (25) but using a Borgwaldt rotary machine RM20/CSR (Borgwaldt, Hamburg, Germany). The puff volume taken under these conditions was $35 \mathrm{~mL}$, with a duration of $2 \mathrm{~s}$ and each puff taken at $60 \mathrm{~s}$ interval. Then the cigarettes were smoked in more intensive conditions (26) including $60 \mathrm{~mL}$ puff volume, with a puff duration of $2 \mathrm{~s}$ each puff taken at $60 \mathrm{~s}$ interval (indicated as 60/60 conditions), 45 $\mathrm{mL}$ puff volume, with a puff duration of $2 \mathrm{~s}$ and each puff taken at $30 \mathrm{~s}$ interval (indicated as 45/30 conditions), and 60 $\mathrm{mL}$ puff volume, with a puff duration of $2 \mathrm{~s}$ and each puff taken at $30 \mathrm{~s}$ interval (indicated as 60/30 conditions). The cigarette butts from the cigarettes were also collected for the analysis of nicotine content.

\section{Exhaled smoke collection}

The smoke collection of exhaled smoke from the human subjects was done by a vacuum assisted procedure. This pro- 


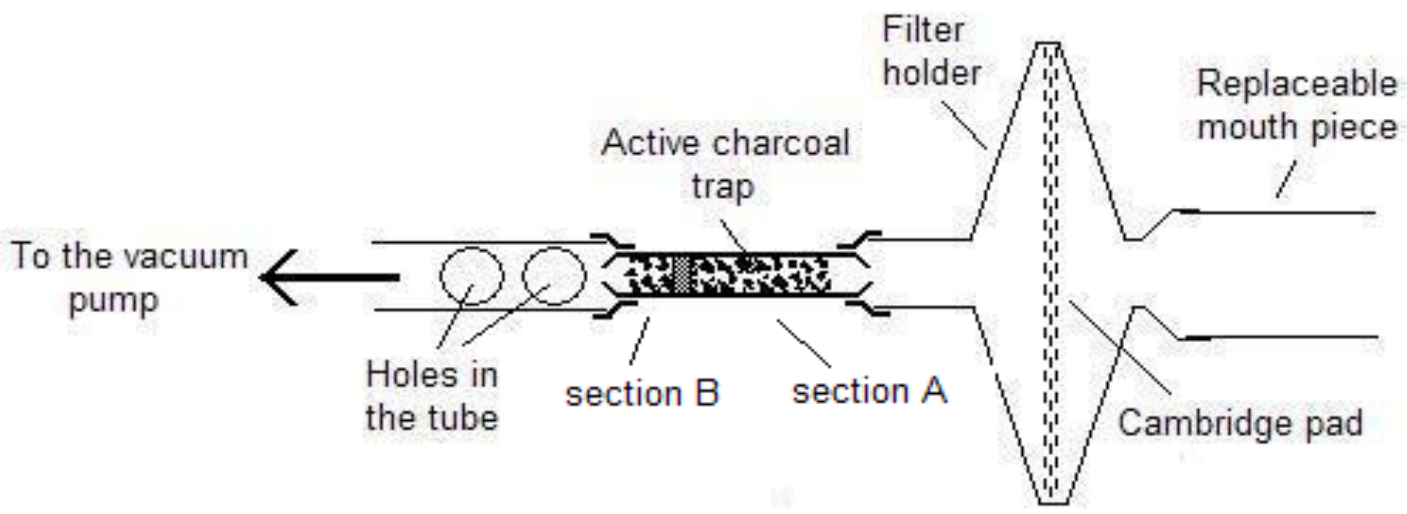

Figure 1. Schematic drawing of the device used for the collection of exhaled cigarette smoke

cedure has been used in order to avoid the excessive strain that would be necessary to otherwise overcome the flow resistance of the Cambridge pad. The device is schematically shown in Figure 1. The device consisted of a $92 \mathrm{~mm}$ Cambridge holder and pad having at one opening a replaceable mouth piece (Atlantic Medical Solutions, Charlotte, NC 28217, USA), and at the other opening being connected to the absorbent charcoal trap (ORBO ${ }^{\mathrm{TM}}-32$ Small trap). The Cambridge pad retains the particulate phase smoke component, while the trap was added for the collection of vapor phase smoke components. The trap was of the same type as that used for collection of vapor phase components from a smoking machine. A diaphragm vacuum pump which can aspirate up to $2.2 \mathrm{~m}^{3} / \mathrm{h}$ (Vacuubrand $\mathrm{GmBH}$, Wertheim, Germany) was attached to the trap. The flows through the trap were measured and were about 250 $\mathrm{mL} / \mathrm{sec}$ during collection. The tube connecting the trap to the pump has two large holes to the exterior, which can be covered with the fingers. When no smoke is exhaled, the holes in the tube to the vacuum pump are kept open such that air from the surrounding is aspirated by the pump without passing the filter and the trap. During smoke exhaling, the smoker blows the smoke through the replaceable mouth piece. At the same time the holes in the tube are covered, such that the exhaled smoke is aspirated through the Cambridge pad and the charcoal trap. This allows the exhaled smoke to be collected without additional strain on the smoker. The device shown in Figure 1 has been used by ten human subjects selected to smoke their preferred brand. Each subject smoked three cigarettes within one hour, and the exhaled smoke was collected. The smoking was performed in an environment familiar to the smoker (office) with as little as possible change from typical conditions. No measurements were made on inhalation volume or breathhold duration. The cigarettes were previously conditioned under FTC recommendations (25). The cigarette butts from the smokers were collected for nicotine analysis. In addition to exhaled smoke, the breath without smoking was collected from one smoker as a background check. The measurement was done by collecting the exhaled air from 24 breaths (mimicking the number of puffs from three cigarettes) after one hour of smoking the last cigarette.

\section{Chromatographic analysis of benzene and toluene in smoke}

The analysis of benzene and toluene was performed only in the vapor phase of cigarette smoke using a GC/FID (flame ionization detection) procedure. The absorbent charcoal from section A of the ORBO tube was transferred into a $4 \mathrm{~mL}$ vial to which $1 \mathrm{~mL} \mathrm{CS}$. was added (Aldich/Sigma, Saint Louis, MO 63178-9916, USA). The $\mathrm{CS}_{2}$ also contained $100 \mu \mathrm{g} / \mathrm{mL}$ of 2-chloropentane used as a chromatographic standard. The charcoal was kept in the capped vials containing $\mathrm{CS}_{2}$ for one hour at room temperature with occasional stirring. After the extraction, part of the $\mathrm{CS}_{2}$ solution was removed with a pipette, transferred into a $\mathrm{GC}$ vial, and analyzed. The proof that the benzene and toluene were completely retained by the section $A$ of the charcoal tube was obtained by analyzing the section B of the ORBO tube for several samples that collected vapor phase smoke from machine or from human smoked cigarettes. The same procedure of extraction as for section A of the ORBO tube was used for section B samples. The GC analysis was performed on a $6890 \mathrm{GC}$ instrument (Agilent, Wilmington, DE 19808, USA), with a FID detector. The parameters for the instrument setup are given in Table 2.

A typical chromatogram obtained under the conditions from Table 2 for a 1R5F Kentucky reference cigarette is shown in Figure 2. The $\mathrm{CS}_{2}$ extract of section $\mathrm{B}$ of the charcoal trap was also analyzed by the same GC procedure. No peaks for benzene or toluene were detected either for machine smoked cigarette, or for human smokers. This indicated that the two compounds are retained efficiently from the vapor phase of cigarette smoke on the section A of the absorbent tubes. The flow through the charcoal trap using machine smoking was within the recommended limits by the trap manufacturer. The flow of gases through the trap during exhaled smoke collection was higher than the recommended maximum flow. For this reason, the section B of the trap was analyzed for all human smokers. No benzene or toluene was detected in these analyses indicating that the retention was complete in section A of the charcoal trap.

The quantitation of benzene and toluene was obtained using six standards, each run twice. Curves representing quantity 
Table 2. Gas chromatography (GC) operating parameters ${ }^{a}$

\begin{tabular}{l|l|l|l}
\hline Parameter & Description & Parameter & Description \\
\hline GC column & $\mathrm{DB}-1$ & Inlet mode & Split \\
Column dimensions & $30 \mathrm{~m}, 0.32 \mathrm{~mm}$ i.d. & Injection volume & $2.0 \mathrm{LL}$ \\
Film thickness & $2.0 \mu \mathrm{m}$ & Split ratio & $5: 1$ \\
Initial oven temperature & $40{ }^{\circ} \mathrm{C}$ & Split flow & $6.1 \mathrm{~mL} / \mathrm{min}$ \\
Initial time & $3.0 \mathrm{~min}$ & Carrier gas & Helium \\
Oven ramp rate & $2{ }^{\circ} \mathrm{C} / \mathrm{min}$ & Flow mode & $\mathrm{Constant} \mathrm{flow}$ \\
Oven final first ramp & $110^{\circ} \mathrm{C}$ & Flow rate & $1.2 \mathrm{~mL} / \mathrm{min}$ \\
Final time first ramp & $0 \mathrm{~min}$ & Nominal initial pressure & $6.3 \mathrm{psi}$ \\
Oven ramp rate & $15{ }^{\circ} \mathrm{C} / \mathrm{min}$ & $\mathrm{GC}$ outlet & Atmosphere $(\mathrm{FID})$ \\
Oven final temperature & $280{ }^{\circ} \mathrm{C}$ & FID temperature & $280{ }^{\circ} \mathrm{C}$ \\
Final time & $0 \mathrm{~min}$ & FID H flow & $30 \mathrm{~mL} / \mathrm{min}$ \\
Total run time & $17.13 \mathrm{~min}$ & FID air flow & $400 \mathrm{~mL} / \mathrm{min}$ \\
Inlet temperature & $280{ }^{\circ} \mathrm{C}$ & FID makeup gas flow & $28.8 \mathrm{~mL} / \mathrm{min}$ \\
\hline
\end{tabular}

* Abbreviation: FID = Flame ionization detection

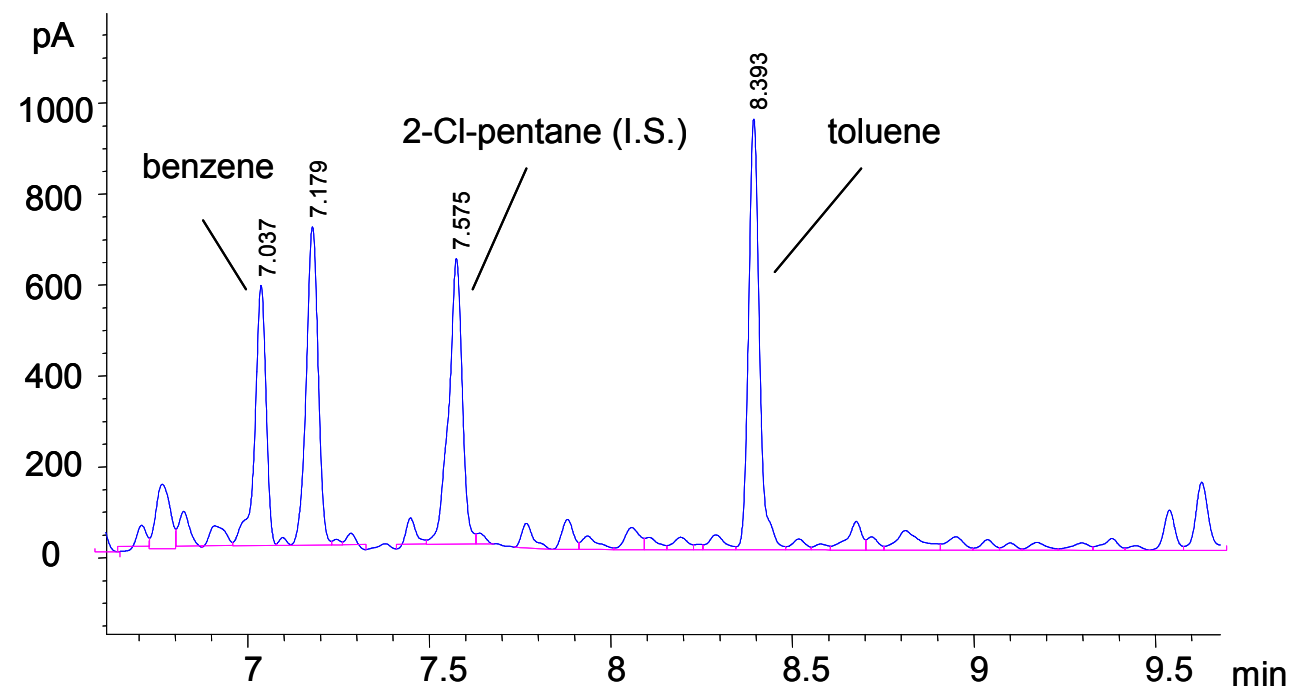

Figure 2. Typical GC chromatogram showing benzene, toluene and the internal standard peaks for a $1 \mathrm{R} 5 \mathrm{~F}$ Kentucky reference cigarette

vs. peak areas were generated for the two compounds. The calibration curves were linear and the $R^{2}$ values for the dependence were above 0.998 for both analytes. The normalization of the peak areas by the area of the internal standard was not used since its use did not improve the relative standard deviation ( $\mathrm{RSD} \%$ ) of the results. The area of the internal standard was used only to verify the reproducibility of the chromatographic analysis.

\section{Analysis of toluene in particulate and vapor phase of cigarette smoke}

One particular aspect of the measurement of toluene for the evaluation of retention by smokers is that toluene was measured only in vapor phase of the cigarette smoke. Differently from benzene that is present mainly in the vapor phase of mainstream smoke, toluene is also present in the particulate phase. In order to prove that toluene is present mainly in the vapor phase of cigarette smoke, its partition between particulate phase and vapor phase was separately evaluated for eleven different cigarettes (each analyzed three times). This analysis started by collecting both parti- culate phase and vapor phase of cigarette smoke. The smoking was done using a Borgwaldt RM20 CSR smoking machine, working in conditions similar to FTC. Smoke from 20 cigarettes was collected in each run. The collection of particulate phase smoke was performed using an electrostatic precipitator (SL30 from Spellman High Voltage Electronic Corp., Hauppauge, NY 11788, USA) that was weighed before and after the smoking to measure the amount of total particulate matter (TPM). The exit of the electrostatic precipitator was connected to four traps in series, each containing glass beads and $5 \mathrm{~mL}$ acetone for the collection of vapor phase smoke. The first trap was cooled in ice water, and the other three traps were cooled with dry ice/isopropanol mixture. The acetone in the traps contained 1,1,1,3,3,3hexafluoroisopropanol as an internal standard. The total particulate matter from the electrostatic precipitator was also dissolved in acetone containing the same internal standard. The final concentration of the internal standard in the acetone solutions was $200 \mathrm{~nL} / \mathrm{mL}(323 \mu \mathrm{g} / \mathrm{mL})$. The extracts were analyzed by GC/MS (GC/MSD 6890/5973, Agilent Wilmington, DE 19808, USA). The GC/MS conditions are given in Table 3. 
Table 3. Gas chromatography/mass spectrometry (GC/MS) parameters for the evaluation of the distribution of toluene between particulate phase and vapor phase ${ }^{a}$

\begin{tabular}{ll}
\hline Parameter & Description \\
\hline GC column & DB-Waxetr \\
Column dimensions & $30 \mathrm{~m}$ long, $0.32 \mathrm{~mm}$ i.d. \\
Film thickness & $0.50 \mu \mathrm{m}$ \\
Carrier gas & Helium \\
Flow mode & Constant flow \\
Flow rate & $1.5 \mathrm{~mL} / \mathrm{min}$ \\
Initial oven temperature & $37{ }^{\circ} \mathrm{C}$ \\
Initial time & $2.0 \mathrm{minutes}$ \\
Oven ramp rate & $2.5{ }^{\circ} \mathrm{C} / \mathrm{mm}$ \\
Oven final temperature & $230{ }^{\circ} \mathrm{C}$ \\
Final time & $25.8 \mathrm{~min}$ \\
Inlet mode & $\mathrm{Splitless}$ \\
Inlet temperature & $250{ }^{\circ} \mathrm{C}$ \\
Injection volume & $1 \mu \mathrm{L}$ \\
MSD transfer line heater & $250{ }^{\circ} \mathrm{C}$ \\
lon source temperature & $230{ }^{\circ} \mathrm{C}$ \\
Quadrupole temperature & $150{ }^{\circ} \mathrm{C}$ \\
MSD EM offset & $350 \mathrm{~V}$ \\
MSD solvent delay & $5.0 \mathrm{~min}$ \\
MSD acquisition mode & $\mathrm{TIC}$ \\
Mass range & 33 amu - 550 amu \\
\hline
\end{tabular}

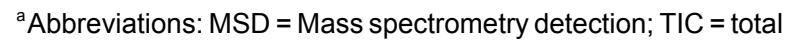
ion chromatogram.

\section{Analysis of nicotine in the cigarette butts}

Previously reported results showed that the nicotine in the cigarette butt ( $1 \mathrm{~cm}$ from the mouth end) has a linear dependence on the amount of nicotine collected on the Cambridge pad $(27,28)$. In this study, dependence equations between the level of benzene and toluene in smoke and the nicotine level in the cigarette butts were obtained. For the analysis of nicotine in the cigarette butt, the smoked butts were collected and cut at lengths of $1 \mathrm{~cm}$. The $1 \mathrm{~cm}$ mouth end portions were put together from each smoker, or from the smoking machine, and were extracted with $20 \mathrm{~mL}$ methanol containing an internal standard (dodecanol). The level of nicotine was measured using a standard GC procedure (29).

\section{RESULTS AND DISCUSSION}

\section{Discussion on benzene and toluene analysis}

Benzene is present in mainstream cigarette smoke mainly in vapor phase (30). Toluene is also present mainly in vapor phase of mainstream cigarette smoke but low levels are also present in particulate phase. In the first part of the study the distribution of toluene between particulate and vapor phase of cigarette smoke was evaluated. The ratios of the normalized peak areas (by the internal standard) obtained from particulate phase vs. vapor phase ( $\mathrm{PP} / \mathrm{VP} \%)$ are given in Table 4. The same table also provides the measured 'tar' values for each run. As seen from Table 4, the toluene is present between $94 \%$ to $97 \%$ in the vapor phase portion of the cigarette smoke. Therefore, the measurement of the retention of toluene only from the vapor phase provides a good estimation of the retention by the smoker of this compound.

The analysis of benzene and toluene by the GC/FID analytical procedure was done initially for $2 \mathrm{R} 4 \mathrm{~F}$ and $1 \mathrm{R} 5 \mathrm{~F}$ Kentucky reference cigarettes machine smoked in FTC type conditions. This was performed for the verification of the procedure accuracy. The average values and RSD\% for benzene and toluene in vapor phase from five replicates, and some values reported in literature are given in Table 5 for $2 \mathrm{R} 4 \mathrm{~F}$ Kentucky reference cigarette and in Table 6 for 1R5F Kentucky reference cigarettes. As seen from Table 5 and Table 6 , the agreement with other data for the benzene and toluene are very good, except for toluene in 1R5F cigarette where the number reported in literature is relatively higher. The $\mathrm{RSD} \%$ from the present work can be considered very good.

Generation of the dependence charts between the level of benzene and toluene for machine smoked cigarettes and cigarette butt nicotine

The analysis of benzene and toluene was performed initially for machine smoked cigarettes using different puffing conditions. At the same time with this analysis, nicotine was analyzed in the cigarette butts. Dependence charts between the level of benzene and toluene in vapor phase smoke as a function of the nicotine level in the cigarette butts were

Table 4. The distribution of toluene between particulate phase (PP) and vapor phase (VP) expressed as PP/VP\% and the 'tar' levels (mg/cig) for eleven different cigarettes

\begin{tabular}{|c|c|c|c|c|c|c|c|c|}
\hline Cigarette & 'Tar' mg/cig & PP/VP\% & Cigarette & 'Tar' mg/cig & PP/VP\% & Cigarette & 'Tar' mg/cig & PP/VP\% \\
\hline \multirow[t]{3}{*}{ Cig 1} & 9.09 & 3.11 & \multirow[t]{3}{*}{ Cig 5} & 10.13 & 3.66 & \multirow[t]{3}{*}{ Cig 9} & 8.92 & 2.79 \\
\hline & 8.85 & 3.10 & & 10.07 & 3.71 & & 8.92 & 2.82 \\
\hline & 8.39 & 3.03 & & 10.25 & 4.22 & & 8.97 & 2.72 \\
\hline \multirow[t]{3}{*}{ Cig 2} & 10.73 & 5.64 & \multirow[t]{3}{*}{ Cig 6} & 9.40 & 3.17 & \multirow[t]{3}{*}{ Cig 10} & 9.91 & 3.24 \\
\hline & 9.29 & 4.88 & & 9.52 & 4.05 & & 9.90 & 3.03 \\
\hline & 10.30 & 4.72 & & 8.90 & 4.20 & & 9.56 & 3.35 \\
\hline \multirow[t]{3}{*}{ Cig 3} & 9.81 & 3.84 & \multirow[t]{3}{*}{ Cig 7} & 10.45 & 3.21 & \multirow[t]{3}{*}{ Cig 11} & 10.09 & 3.09 \\
\hline & 9.78 & 3.44 & & 10.28 & 2.98 & & 10.31 & 3.67 \\
\hline & 9.78 & 3.22 & & 10.36 & 3.13 & & 10.32 & 3.78 \\
\hline \multirow[t]{3}{*}{ Cig 4} & 10.63 & 5.77 & \multirow[t]{3}{*}{ Cig 8} & 11.01 & 3.41 & & & \\
\hline & 10.53 & 4.97 & & 10.46 & 4.57 & & & \\
\hline & 10.60 & 5.90 & & 10.43 & 4.00 & & & \\
\hline
\end{tabular}


Table 5. Mainstream yields of benzene and toluene for $2 \mathrm{R} 4 \mathrm{~F}$ cigarette from this work and reported in the literature

\begin{tabular}{l|c|c|c|c}
\hline Compound & This work average & This work RSD\% ${ }^{\text {a }}$ & Ref (31) average & Ref (31) RSD\% \\
\hline Benzene $\mu \mathrm{g} / \mathrm{cig}$ & 41.4 & 2.47 & 43.4 & 3.0 \\
Toluene $\mu \mathrm{g} / \mathrm{cig}$ & 62.1 & 3.22 & 64.9 & 4.0 \\
'Tar' $\mathrm{mg} / \mathrm{cig}$ & 11.20 & & & \\
\hline
\end{tabular}

${ }^{\mathrm{a}} \mathrm{RSD} \%$ = Relative Standard Deviation \%

Table 6. Mainstream yields of benzene and toluene for $1 \mathrm{R} 5 \mathrm{~F}$ cigarette from this work and reported in the literature

\begin{tabular}{l|c|c|c|c}
\hline Compound & This work average & This work RSD\% & Ref (32) average & Ref (32) RSD\% \\
\hline Benzene $\mu \mathrm{g} / \mathrm{cig}$ & 11.2 & 5.51 & 13 & - \\
Toluene $\mu \mathrm{g} / \mathrm{cig}$ & 14.6 & 4.02 & 18 & - \\
'Tar' $\mathrm{mg} / \mathrm{cig}$ & 2.24 & & & \\
\hline
\end{tabular}

Table 7. Measured and calculated values in $\mu \mathrm{g} / \mathrm{cig}$ for benzene and toluene from machine smoked cigarettes

\begin{tabular}{l|c|c|c|c}
\hline \multirow{2}{*}{ Compound } & \multicolumn{4}{|c}{ Smoking condition } \\
\cline { 2 - 5 } & FTC & $60 / 60$ & $45 / 30$ & $60 / 30$ \\
\hline Benzene measured $(\mu \mathrm{g} / \mathrm{cig})$ & 45.13 & 68.70 & 84.36 & 98.08 \\
Benzene calculated $(\mu \mathrm{g} / \mathrm{cig})$ & 47.80 & 63.94 & 86.94 & 97.60 \\
Toluene measured $(\mu \mathrm{gig})$ & 64.29 & 106.30 & 139.84 & 151.46 \\
Toluene calculated $(\mu \mathrm{g} / \mathrm{cig})$ & 70.35 & 98.06 & 137.58 & 155.90 \\
Butt nicotine $(\mathrm{mg} / \mathrm{cig})$ & 0.19 & 0.26 & 0.36 & 0.40 \\
\hline
\end{tabular}

Table 8. The levels in $\mu \mathrm{g} / \mathrm{cig}$ of benzene and toluene in the exhaled smoke and the level of nicotine in the cigarette butt (mg/cig) for each of the human subjects

\begin{tabular}{l|c|c|c|c|c|c|c|c|c|c}
\hline Compound & $\begin{array}{c}\text { Exhaled } \\
1\end{array}$ & $\begin{array}{c}\text { Exhaled } \\
2\end{array}$ & $\begin{array}{c}\text { Exhaled } \\
3\end{array}$ & $\begin{array}{c}\text { Exhaled } \\
4\end{array}$ & $\begin{array}{c}\text { Exhaled } \\
5\end{array}$ & $\begin{array}{c}\text { Exhaled } \\
6\end{array}$ & $\begin{array}{c}\text { Exhaled } \\
7\end{array}$ & $\begin{array}{c}\text { Exhaled } \\
8\end{array}$ & $\begin{array}{c}\text { Exhaled } \\
9\end{array}$ & $\begin{array}{c}\text { Exhaled } \\
10\end{array}$ \\
\hline Benzene $(\mu \mathrm{g} / \mathrm{cig})$ & 4.57 & 4.03 & 5.37 & 3.17 & 1.79 & 1.27 & 2.18 & 3.46 & 1.44 & 1.44 \\
Toluene $(\mu \mathrm{g} / \mathrm{cig})$ & 5.78 & 7.61 & 8.01 & 3.76 & 1.74 & 1.29 & 2.59 & 5.39 & 1.53 & 1.67 \\
Butt nicotine (in $\mathrm{mg} / \mathrm{cig})$ & 0.20 & 0.18 & 0.18 & 0.24 & 0.27 & 0.20 & 0.26 & 0.12 & 0.20 & 0.32 \\
\hline
\end{tabular}

obtained. The levels of benzene and toluene for the cigarettes smoked in FTC, 60/60, 45/30, and 60/30 conditions, showed a linear dependence as a function of the corresponding level of nicotine in the smoked butts. The equations of the correlation lines were:

$$
\begin{aligned}
& \text { Benzene }(\mu \mathrm{g} / \mathrm{cig})=228.34 \cdot \text { Butt nic. }(\mathrm{mg} / \mathrm{cig})+5.4215[1] \\
& \text { Toluene }(\mu \mathrm{g} / \mathrm{cig})=392.27 \cdot \text { Butt nic. }(\mathrm{mg} / \mathrm{cig})-2.4585[2]
\end{aligned}
$$

Using these equations and the levels of nicotine in the cigarette butts, the levels of benzene and toluene in smoke can be calculated. The verification obtained by comparing the calculated results with the measured values given in Table 7 for machine smoked cigarettes, showed very good agreement proving the validity of the approach.

\section{Analysis of benzene and toluene in the exhaled smoke and the calculation of delivered levels}

Before the analysis of benzene and toluene in the exhaled smoke, an evaluation of the background level in the breath of a smoker when no cigarette was smoked within one hour has been measured. It was found that only very low traces of these compounds were detected in exhaled breath. However, the measured levels were equivalent to values between 0.05 and $0.1 \mu \mathrm{g} / \mathrm{cig}$, and were considerably lower than typical errors affecting the results. In addition to that, the peaks with retention time corresponding to benzene and toluene were not positively identified as these compounds (since the detection was done using FID only). It was concluded that any benzene or toluene from the breath without smoking had no effect on the results regarding the retention of these compounds.

The level of benzene and toluene in the exhaled smoke was analyzed for ten smokers and the results are reported in $\mu \mathrm{g} / \mathrm{cig}$ in Table 8 . The table also indicates the amount of nicotine in $\mathrm{mg} / \mathrm{cig}$ measured in the collected cigarette butts from each smoker. Using the nicotine levels from the cigarette butts for each smoker, and Eqns. [1] and [2] the delivered levels of benzene and toluene were calculated. The results are given in Table 9.

\section{Calculation of the retention \% of benzene and toluene by human smokers}

From the results for the exhaled smoke given in Table 8 and those calculated for the delivered smoke given in Table 9 the retention of benzene and toluene can be calculated for each smoker, using the expression:

$$
\text { Retention } \%=100-\frac{(\text { exhaled level })}{(\text { delivered level })} \cdot 100
$$


Table 9. Calculated levels in $\mu \mathrm{g} / \mathrm{cig}$ of benzene and toluene in the delivered smoke for each of the human subjects

\begin{tabular}{|c|c|c|c|c|c|c|c|c|c|c|}
\hline Compound & $\begin{array}{c}\text { Delivered } \\
1 \\
\end{array}$ & \begin{tabular}{|c|} 
Delivered \\
2 \\
\end{tabular} & $\begin{array}{c}\text { Delivered } \\
3 \\
\end{array}$ & $\begin{array}{c}\text { Delivered } \\
4\end{array}$ & $\begin{array}{c}\text { Delivered } \\
5\end{array}$ & $\begin{array}{c}\text { Delivered } \\
6\end{array}$ & $\begin{array}{c}\text { Delivered } \\
7 \\
\end{array}$ & \begin{tabular}{|c} 
Delivered \\
8 \\
\end{tabular} & $\begin{array}{c}\text { Delivered } \\
9\end{array}$ & $\begin{array}{c}\text { Delivered } \\
10 \\
\end{array}$ \\
\hline Benz & 50.86 & 46.07 & 46.75 & 59.99 & 67.53 & 51.23 & 65.25 & 31.91 & 49.95 & 77.81 \\
\hline Toluene ( $\mu \mathrm{g} / \mathrm{cig})$ & 75.60 & 67.37 & 68.54 & 91.29 & 104.24 & 76.39 & 100.32 & 43.04 & 74.03 & 121.89 \\
\hline
\end{tabular}

Table 10. Retention $\%$ of benzene and toluene in the delivered smoke for each of the human subjects

\begin{tabular}{|c|c|c|c|c|c|c|c|c|c|c|c|c|c|}
\hline No. & Compound & $\begin{array}{c}\text { Ret. \% } \\
1\end{array}$ & $\begin{array}{c}\text { Ret. \% } \\
2\end{array}$ & $\begin{array}{c}\text { Ret. \% } \\
3\end{array}$ & $\begin{array}{l}\text { Ret. \% } \\
4\end{array}$ & $\begin{array}{l}\text { Ret. \% } \\
5\end{array}$ & $\begin{array}{l}\text { Ret. \% } \\
6\end{array}$ & $\begin{array}{c}\text { Ret. \% } \\
7\end{array}$ & $\begin{array}{c}\text { Ret. \% } \\
8\end{array}$ & $\begin{array}{c}\text { Ret. \% } \\
9\end{array}$ & $\begin{array}{c}\text { Ret. \% } \\
10\end{array}$ & Average & RSD\% \\
\hline 1 & Benzene & 91.01 & 91.25 & 88.51 & 94.72 & 97.35 & 97.52 & 96.66 & 89.16 & 97.12 & 98.15 & 94.14 & 3.77 \\
\hline 2 & Toluene & 92.35 & 88.70 & 88.31 & 95.88 & 98.33 & 98.31 & 97.42 & 87.48 & 97.93 & 98.63 & 94.34 & 4.64 \\
\hline
\end{tabular}

The retention values are given in Table 10 for each smoker. As seen from Table 10, the retentions of both benzene and toluene are in the range of $87 \%$ to $99 \%$. The values for toluene retention are in excellent agreement with the data reported in a recent review of cigarette smoke retention (15), which references an internal BAT report (33) showing toluene retention between $87 \pm 8 \%$ to $92 \pm 4 \%$. The same internal report indicates that the benzene retention is around $75 \pm 7 \%$, values that are surprisingly far from toluene retention. Higher values of retention for benzene were found in this study ( $89 \%$ to $98 \%$ ), which better concur with the retention values found for toluene. The lower limits of retention for benzene and toluene are still unexpectedly low compared to the retention of bi-and tricyclic aromatic hydrocarbons, which have retentions from cigarette smoke above $95 \%$. This is probably caused by the fact that monocyclic aromatic hydrocarbons are present practically only in the vapor phase of cigarette smoke and at considerably higher levels than bi- and tricyclic aromatic hydrocarbons which are found only in particulate phase.

\section{CONCLUSIONS}

This study provides information of the retention of benzene and toluene from mainstream cigarette smoke. The evaluated cigarette was a common commercially available product with $10.6 \mathrm{mg}$ 'tar', and the test was performed on ten subjects, each smoking three cigarettes. The benzene was retained at levels of $89 \%$ to $98 \%$, toluene being retained at similar levels, between $87 \%$ and $99 \%$. The only other result reported in the literature (15) for benzene and toluene comes from an internal BAT study performed in 1973. The agreement with this study is excellent for toluene, but benzene is shown to be retained at higher levels than previously reported.

\section{REFERENCES}

1. Lehmann, K.B.: Untersuchungen im Rauch des Tabaks [Investigation of the smoke from tobacco]; München med. Wochenschrift LV (1908) 723-725.

2. Isaac, R.F. and M.J. Rand: Cigarette smoking and plasma levels of nicotine; Nature 236 (1972) 308-310.

3. McAughey, J.J., D.K. Knight, A. Black, and C.J. Dickens: Environmental tobacco smoke retention in humans from measurements of exhaled smoke composition; Inhalat. Toxicol. 6 (1994) 615-631.

4. Armitage, A.K., C.T. Dollery, C.F. George, T.H. Houseman, P.J. Lewis, and D.M. Turner: Absorbtion and metabolism of nicotine from cigarettes; Brit. Med. J. 4 (1975) 313-316.

5. Gori, G.B., N.L. Benowitz, and C.J. Lynch: Mouth versus deep airways absorption of nicotine in cigarette smokers; Pharmacol. Biochem. Behav. 25 (1986) 1181-1184.

6. Armitage, A.K., M. Dixon, B.E. Frost, D.C. Mariner, and N.M. Sinclair: The effect of tobacco blend additives on the retention of nicotine and solanesol in the human respiratory tract and on subsequent plasma nicotine concentrations during cigarette smoking; Chem. Res. Toxicol. 17 (2004) 537-544.

7. Armitage, A.K., M. Dixon, B.E. Frost, D.C. Mariner, and N.M. Sinclair: The effect of inhalation volume and breath-hold duration on the retention of nicotine and solanesol in the human respiratory tract and on subsequent plasma nicotine concentrations during cigarette smoking; Beitr. Tabakforsch. Int. 21 (2004) 240-249.

8. Bernstein, D.M.: A review of the influence of particle size, puff volume, and inhalation pattern on the deposition of cigarette smoke particles in the respiratory tract; Inhalat. Toxicol. 16 (2004) 675-689.

9. Broday, D.M. and P.G. Georgopoulos: Growth and deposition of hygroscopic particulate matter in the human lung; Aerosol. Sci. Tech. 34 (2001) 144-159.

10. Davies, C.N.: Deposition of inhaled particles in man; Chemistry and Industry (1974) 441-444.

11. Robinson, R.J., and C.P. Yu: Deposition of cigarette smoke particles in the human respiratory tract; Aerosol. Sci. Tech. 34 (2001) 202-215.

12. Hinds, W., M.W. First, G.L. Huber, and J.W. Shea: A method for measuring the deposition of cigarette smoke during smoking; Am. Ind. Hyg. Assoc. J. 44 (1983) 113-118.

13. Dalhamn, T., M.-L. Edfors, and R. Rylander: Mouth absorption of various compounds in cigarette smoke; Arch. Environ. Health. 16 (1968) 831-835.

14. Dalhamn, T., M.-L. Edfors, and R. Rylander: Retention of cigarette smoke components in human lungs; Arch. Environ. Health. 17 (1968) 746-748.

15. Baker, R.R., and M. Dixon: The retention of tobacco smoke constituents in the human respiratory tract; Inhal.. Toxicol. 18 (2006) 255-294. 
16. Laskowski, K.: Components of tobacco smoke and their absorption in the respiratory system of the smoker; Rocz. Państw. Zak. Hig. [Ann. Natl. Inst. Hyg.] 2 (1951) 139-160.

17. Haagen-Smith A. J., M.F. Brunelle, and J. Hara: Nitrogen oxide content of smokers from different types of tobacco; A.M.A. Arch. Ind. Health, 20 (1959) 399-400.

18. Eagle, J.L., Jr.: Retention of inhaled acetaldehyde in man; J. Pharm. Acol. Exp. Therapeut. 174 (1970) 14-19.

19. Ingebrethsen, B.J.: The physical properties of mainstream cigarette smoke and their relationship to deposition in the respiratory tract; in: Extrapolation of dosimetric relationship for inhaled particles and gases, edited by J.D. Carpo, E.D. Smolko, F.J. Miller, J.A. Graham, and A.W. Haye, Academic Press, New York, 1989, pp. 125-141.

20. Feng. S., S.E. Plunkett, K. Lam, S. Kapur, R. Muhammad, Y. Jin, M. Zimmermann, P. Mendes, R. Kinser, and H.J. Roethig: A new method for estimating the retention of selected smoke constituents in the respiratory tract of smokers during cigarette smoking; Inhal. Toxicol. 19 (2006) 169-179.

21. Moldoveanu, S.C., and F.K. St.Charles: Differences in the chemical composition of particulate phase of inhaled and exhaled cigarette smoke; Beitr. Tabakforsch. Int. 22 (2007) 290-302.

22. Moldoveanu, S.C, W. Coleman III, and J.M. Wilkins: Determination of carbonyl compounds in exhaled cigarette smoke; Beitr. Tabakforsch. Int. 22 (2007) 346-357.

23. Moldoveanu, S.C, W. Coleman III, and J.M. Wilkins: Determination of polycyclic aromatic hydrocarbons in exhaled cigarette smoke; Beitr. Tabakforsch. Int. 23 (2008) 84-96.

24. Moldoveanu, S.C, W. Coleman III, and J.M. Wilkins: Determination of hydroxybenzenes in exhaled cigarette smoke; Beitr. Tabakforsch. Int. 23 (2008) 97-105.

25. Pillsbury, H.C., C.C. Bright, K.J. O’Connor, and F.W. Irish: Tar and nicotine in cigarette smoke; J. Assoc. Off. Anal. Chem. 52 (1969) 458-462.

26. Connoly, G.N., H. Saxner: Memorandum, The Commonwealth of Massachusetts; Exec. Office of Health and Human Services, 19 August, 1997.
27. St.Charles, F.K.: A robust method for determining consumer smoked cigarette yields from filter analytical data; $55^{\text {th }}$ Tobacco Science Research Conference, Program Booklet and Abstracts, Vol. 55, Paper No. 92, 2001, pp. 73-74.

28. Bodnar, J.A., T.J. Collins, S.M. DeBusk, and M.F. Borgerding: Estimation of 'tar' and nicotine yields from individual cigarettes based on filter analysis after smoking; 58 ${ }^{\text {th }}$ Tobacco Science Research Conference, Program Booklet and Abstracts, Vol.58, Paper No. 8, 2004, p 25.

29. ISO 10315: Cigarettes - determination of nicotine in smoke condensates - gas chromatographic method; Second Edition 2000-04-01, International Organization for Standardization, Geneva, Switzerland, 2000 (E).

30. Dong, J.-Z., J.N. Glass, S.C. Moldoveanu: A simple GCMS technique for the analysis of vapor phase mainstream cigarette smoke; J. Microcol. Sep. 12 (2000) 142-152.

31. Chen, P.X., S.C. Moldoveanu: Mainstream smoke chemical analysis for $2 \mathrm{R} 4 \mathrm{~F}$ Kentucky reference cigarettes; Beitr. Tabakforsch. Int. 20 (2003) 448-458.

32. Borgerding, M.F., Bodnar, J.A., Chung, H.L., Mangan, P.P., Mossison, C.C., Risner, C.H., Rogers, J.C., Simmons, D.F., Uhrig, M.S., Wendelboe, F.N., Wingate D.E., and Winkler L.S.: Chemical and biological studies of a new cigarette that primarily heats tobacco. Part I. Chemical composition of mainstream smoke; Food Chem. Toxicol. 36 (1997) 169-182.

33. Backhurst, J.D. and C.T. Martin: Retention of vapor phase constituents of cigarette smoke by the smoker method development; BAT Report L 425-R (1973) as referenced in (15).

Address for correspondence:

Serban Moldoveanu, R.J. Reynolds Tobacco Co. 950 Reynolds Boulevard Winston-Salem, NC 27105

USA

E-mail:moldovs@rjrt.com 